\title{
TEXHИYECRИE HAYRИ
}

УДК: 621.316 .1

ГРНТИ: 44.29.29

\section{РАЗРАБОТКА ТЕХНИЧЕСКИХ РЕШЕНИЙ ПО УСИЛЕНИЮ ЭЛЕКТРИЧЕСКОЙ СЕТИ ДЛЯ СНЯТИЯ СЕТЕВЫХ ОГРАНИЧЕНИЙ, ВЫЗВАННЫХ НЕСИММЕТРИЧНОЙ НАГРУЗКОЙ ТЯГОВЫХ ПОДСТАНЦИЙ}

\section{АННОТАЦИЯ}

Казакул Алексей Александрович Кандидат технических наук, доцент кафедры энергетики и электротехники Амурский государственный университет, г.Благовещенск Смоленский Константин Дмитриевич

Студент 4 курса по специальности

“Электроэнергетика и электротехника” Амурский государственный университет, г.Благовещенск DOI: 10.31618/ESU.2413-9335.2020.2.76.907

В статье предлагаются и оцениваются варианты решений по усилению электрической сети для снятия сетевых ограничений вызванных несимметричной нагрузкой тяговых подстанций.

\section{ABSTRACT}

The article considers solutions for strengthening the electric network to remove network restrictions caused by the asymmetric load of traction substations.

Ключевые слова: несимметричная нагрузка, тяговые подстанции, надежность электроснабжения, усиление электрической сети.

Keywords: asymmetric load, traction substations, reliability of power supply, strengthening of the electric network.

В Схеме и программе развития электроэнергетики Приморского края 2020 - 2024 г.[3] обозначена проблема: ток, протекающий по одной из фаз ВЛ 110 кВ Артемовская ТЭЦ Смоляниново/т в ремонтных и послеаварийных режимах превышает допустимые значения (длительно допустимую токовую нагрузку и аварийно - допустимую токовую нагрузку). Это усложняет организацию ремонтных режимов и приводит к невозможности обеспечения требуемой категории надёжности электроснабжения потребителей [3]. Перегрузка по одной из фаз вызвана работой тяги переменного тока.
Актуальность настоящей работы заключается в том, что решение данной проблемы позволит повысить надежность электроснабжения потребителей Приморского каря в ремонтных и послеаварийных режимах, за счет исключения перегрузки и уменьшения вероятности работы устройств противоаварийной автоматики.

Цель - найти решения по усилению электрической сети для снятия сетевых ограничений, вызванных несимметричной нагрузкой тяговых подстанций. На рисунке 1 предоставлена карта-схема сетей 110 кВ и выше рассматриваемого района Приморского края. 


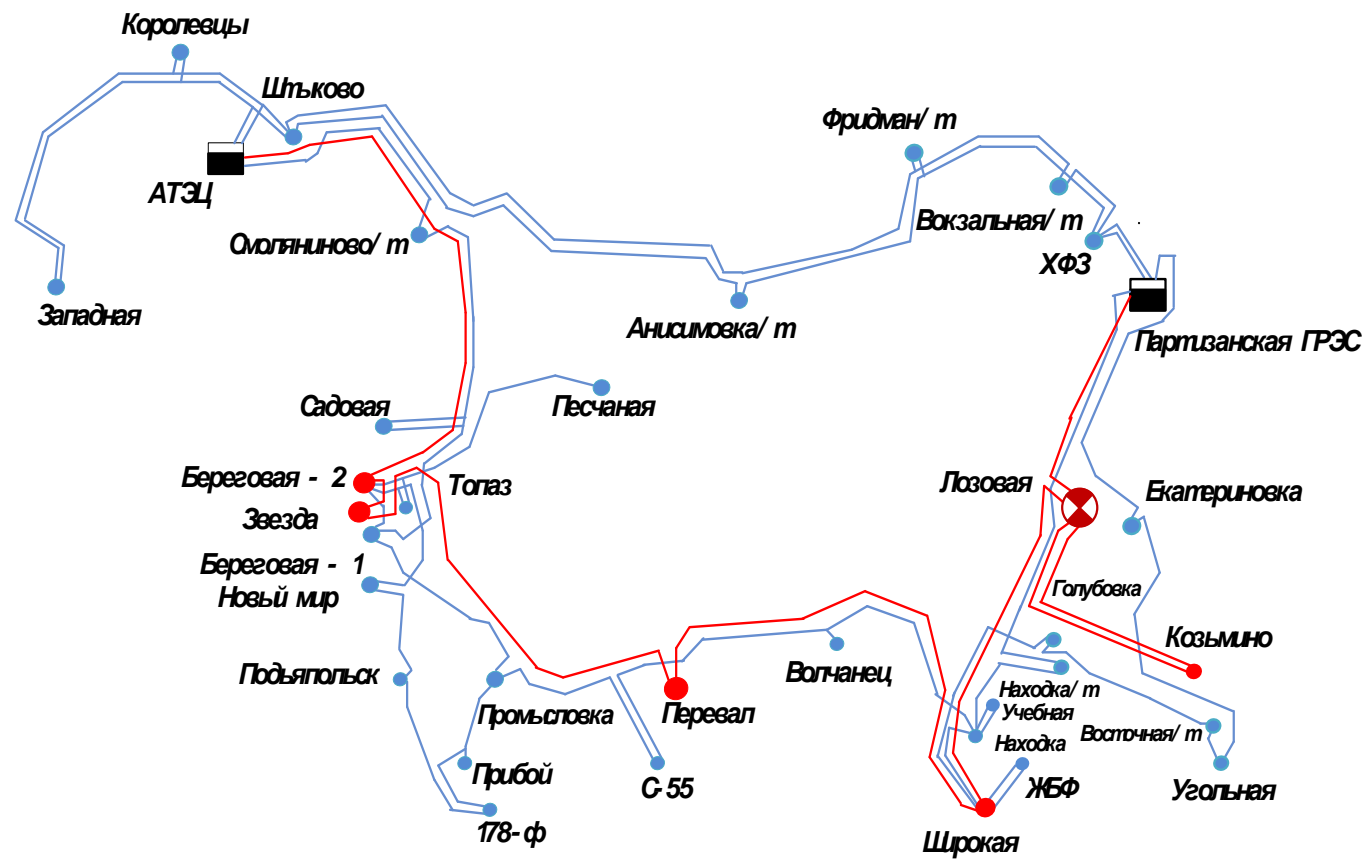

Рисунок 1. Карта схема проектируемого района

Задачами работы являются

- $\quad$ анализ режимов работы сети 110 кВ в района ПС Смоляниново/т в различных схемах;

- разработка вариантов усиления электрической сети;

- $\quad$ анализ режимов работы сети 110 кВ в предложенных вариантах при кратковременных пиковых нагрузках ПС Смоляниново/т;
- проведение технико-экономического сравнения предлагаемых вариантов.

На рисунке 2 предоставлена схема электрической сети 110 кВ Артемовская ТЭЦ Береговая 1.

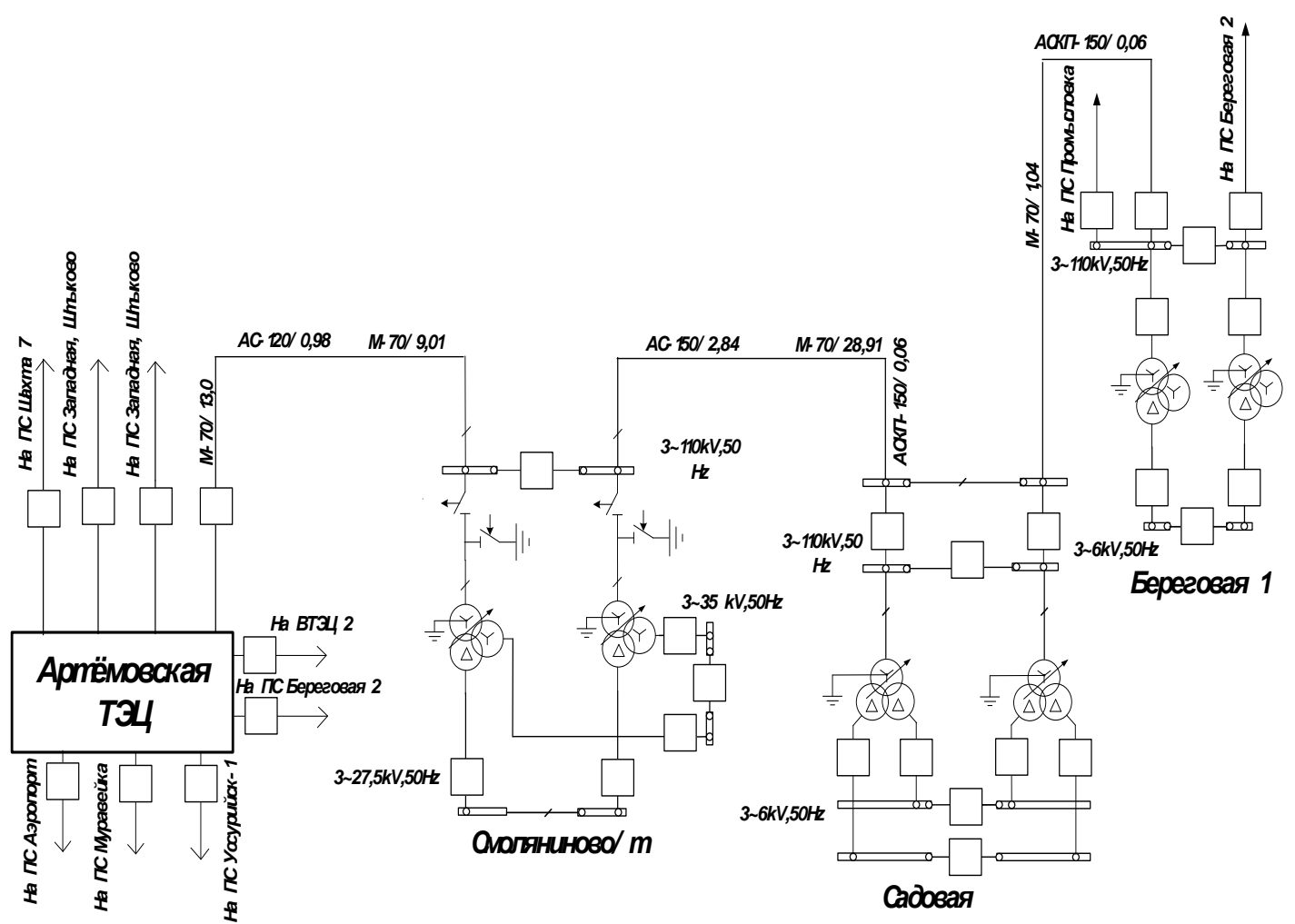

Рисунок 2. Схема электрической сети 110 кВ на участке Артемовская ТЭЦ - Береговая 1

По данным телеизмерений 30 сентября 2019 года по ВЛ 110 кВ Артемовская ТЭЦ -
Смоляниново/т ток доходил до 420 А. Данный ток фиксировался в ремонтной схеме, когда ВЛ 110 кВ 
Смоляново/т - Садовая была выведена в ремонт. Графики токов по фазам приведены на диаграмме 1.

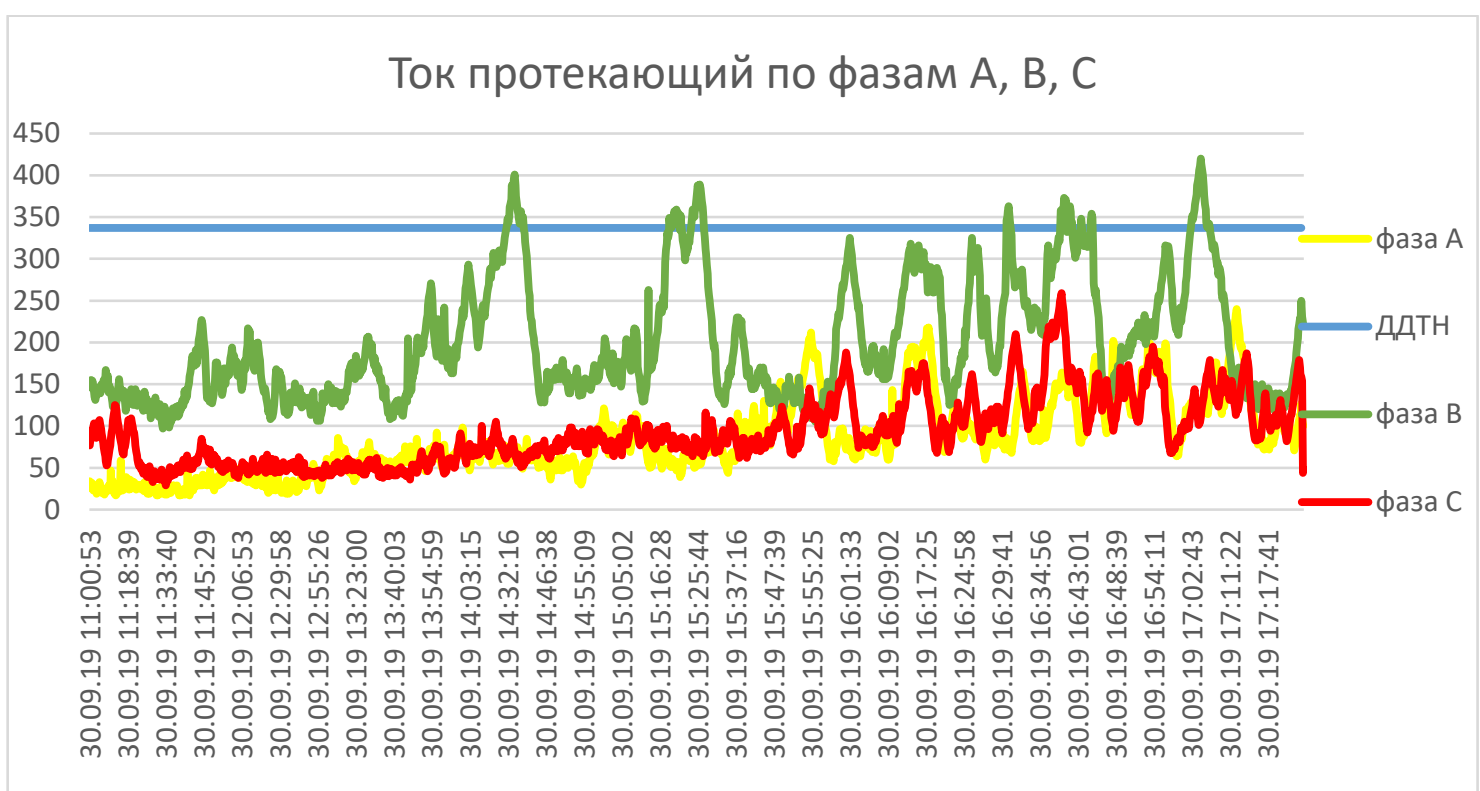

Диаграмма 1. Диаграмма значений фазных токов по ВЛ 110 кВ Артёмовская ТЭЦ - Смоляниново/m 30.09.19.

За рассмотренный период с 11:00 30.09.2019 по 18:00 было выявлено 7 временных интервалов с превышением тока над длительно допустимой токовой нагрузкой (далее - ДДТН) (337 А для $\left.+25^{\circ} \mathrm{C}\right)$ по ВЛ 110 кВ Артёмовская ТЭЦ Смоляниново/т суммарной длительностью 7 мин 23 сек и три временных интервала с превышением аварийно-допустимой токовой нагрузки (далее АДТН $) \quad\left(371\right.$ А для $\left.+25^{\circ} \mathrm{C}\right)$ суммарной длительностью 4 мин. 23 сек. Так как длительность «кратковременных перегрузок» не превышает 20 минут, то считаем что достаточно разработать мероприятия для исключения превышений АДТН в ремонтной схеме , так как это запрещено п. 90 Правил технологического функционирования электроэнергетических систем, утвержденных Постановлением Правительства РФ от 13.08.2018 г. №937 [4]

Для того чтобы разработать мероприятия по исключению превышения АДТН в ремонтных режимах необходимо использовать наибольшую нагрузку, зафиксированную по фазам. В ПВК Rastrwin 3 функционал не позволяет внести разные фазные нагрузки [5]. Поэтому для оценки достаточности предложенных решений используем допущение, что максимальная нагрузка зафиксированная фазе «В» передаётся по каждой из фаз. Таким образом, получим намеренно более сложный режим, позволяющий оценить достаточность предложенных решений.

Для дальнейшего расчета принимаем расчетный ток нагрузки ПС Смоляниново/т 420 А на 110 кВ, зафиксированный устройствами телеизмерений 30.09 .2019 по ВЛ 110 кВ Артёмовская ТЭЦ-Смоляниново/т.
C помощью данных, полученных с телеизмерений найдем мощности для режимов кратковременной нагрузки.

Полная мощность находится по следующей формуле:

$$
S=\sqrt{3} \cdot I \cdot U_{\text {ном }}
$$

где $I$ - текущий ток;

$U_{\text {нои }}$ - номинальное напряжение.

$S=\sqrt{3} \cdot 420 \cdot 110=80,02 \mathrm{MBA}$

Активная мощность находится по следующей формуле:

$$
P=S \cdot \cos \varphi
$$

где - $\cos \varphi$ равен 0,8 [1].

$$
P=80,02 \cdot 0,8=64 M B A
$$

Реактивная мощность находится по формуле

$$
\begin{gathered}
Q=\sqrt{S^{2}-P^{2}} \\
Q=\sqrt{80,02^{2}-64^{2}}=48 M B A
\end{gathered}
$$

Полученную активную и реактивную нагрузку используем при расчете режимов кратковременных перегрузок для оценки достаточной точности предпринятых мероприятий.

1.Для усиления сети рассмотрены следующие варианты: 
1.Вариант№ 1. Замена проводов М-70 и АС120 на АССС 230 на участке сети: Артемовская ТЭЦ - Смоляниново/т - Садовая - Береговая 1 Береговая 2 (ДДТН АССС 230 - 1024 А).
2.Вариант№
2.
Строительство распределительного пункта 110 кВ по схеме
«Четырёхугольник» для разгрузки сетей в ремонтных и послеаварийных режимах.

$$
\text { 3.Вариант№ } 3 . \quad \text { Строительство }
$$
распределительного пункта для секционирования сети в нормальных режимах по схеме Одна рабочая секционированная система шин. Однолинейная схема варианта № 1 показана на рисунке 3 .

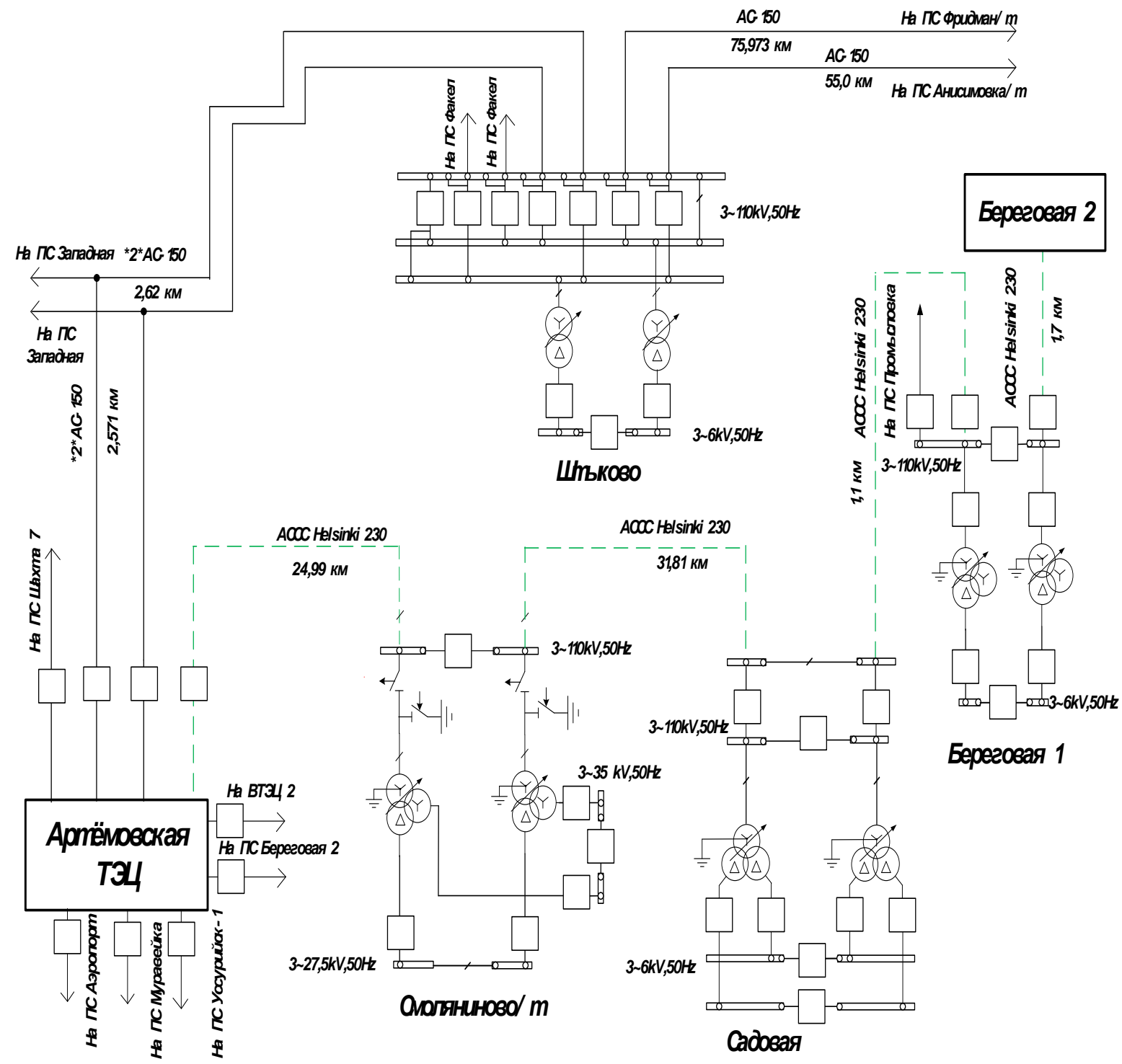

Рисунок 3. Однолинейная схема варианта №1

Вариант № 1 практически не реализуем без снижения нагрузки ПС Смоляниново/т, так как вывод в ремонт одной из питающих её ВЛ 110 кВ будет приводить в перегрузке второй.

В Варианте № 2 подключение РП 110 кВ предлагается выполнить к ВЛ 110 кВ Артемовская ТЭЦ - Смоляниново/т и ВЛ 110 кВ Смоляниново/т - Садовая с врезкой в ВЛ 110 кВ Штыково-
Анисимовка/т. Присоединение осуществляется одноцепными линиями. Достоинством является уменьшение объема сетевого строительства, относительно несложное распределительное устройство для усиления сети 110 кВ, возможность реализации без длительного отключения одной из ВЛ 110 кВ. Однолинейная схема предоставлена на рисунке 4. 


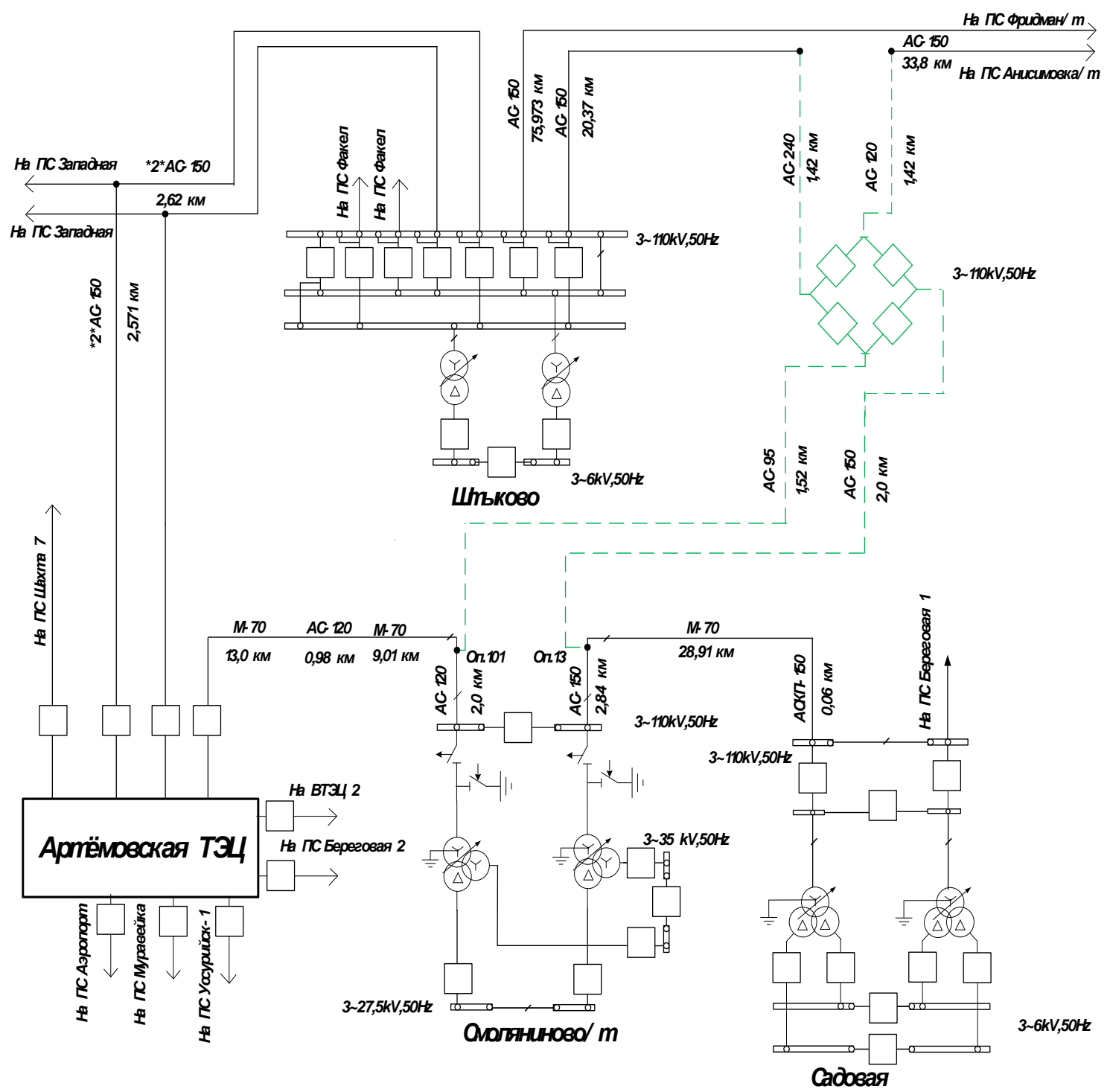

Рисунок 4. Однолинейная схема варианта №2

В Варианте № 3 подключение выполняется врезкой в ВЛ 110 кВ Артемовская ТЭЦ Смоляниново/т , ВЛ $110 \mathrm{kB}$ Смоляниново/т Береговая 1 и ВЛ 110 кВ Штыково-Анисимовка/т. Подключение осуществляется двухцепными линиями к двум параллельным транзитам 110 кВ, что повышается надежность электроснабжения потребителей как тяговой ПС Смоняниново/т, так и придаёт схеме большую гибкость при выводе отдельных элементов сети в ремонт. Схема РП в вариант № 3 - одна рабочая секционированная система шин. 


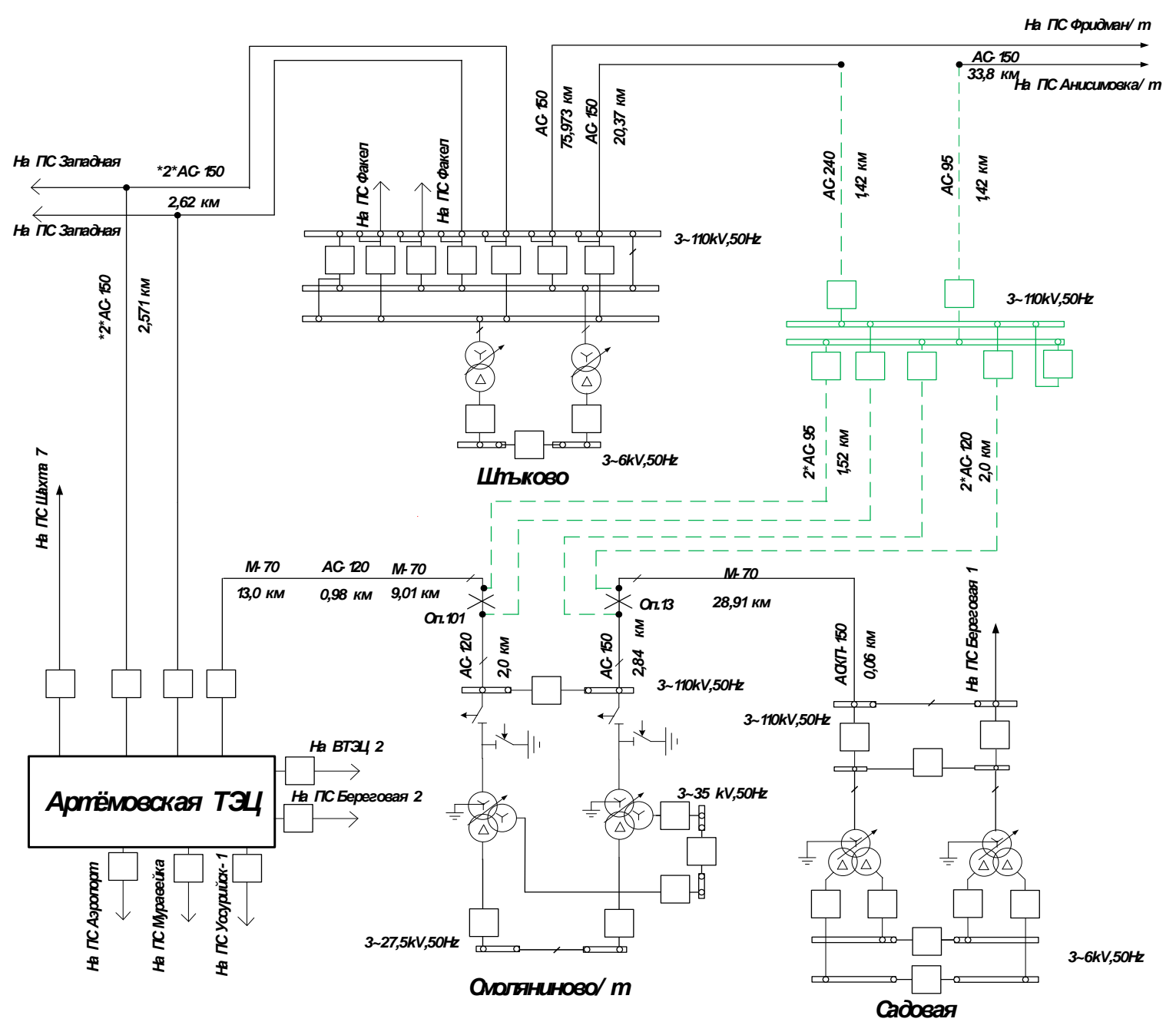

Рисунок 3. Однолинейная схема варианта № 3

Для проверки достаточности предложенных вариантов выполнены расчёты нормальных, ремонтных и послеаварийных режимов согласно Методическим рекомендациям по проектированию развития энергосистем, утвержденных приказом Минэнерго от 30.06.2003г [2]

Результаты расчёта режимов по вариантам приведены в таблицах 1, 2, 3 .

Таблица 1.

\section{Результаты расчета режимов варианта № 1}

\begin{tabular}{|c|c|c|c|}
\hline Наименование ВЛ & Ток, $\mathrm{A}$ & Токовая загрузка ДДТН, \% & Токовая загрузка АДТН, \% \\
\hline \multicolumn{4}{|c|}{ Вывод в ремонт ВЛ 110 кВ Садовая - Смоляниново/т } \\
\hline ВЛ 110 кВ АТЭЦ - Смоляниново/т & 444 & 43.4 & 38.4 \\
\hline ВЛ 110 кВ Береговая $-2-$ Береговая-1 & 150 & 14.6 & 12.9 \\
\hline \multicolumn{4}{|c|}{ Вывод в ремонт ВЛ 110 кВ Береговая - 1 - Садовая } \\
\hline ВЛ 110 кВ АТЭЦ - Смоляниново/т & 453 & 44.2 & 39.1 \\
\hline ВЛ 110 кВ Смоляниново/т - Садовая & 12 & 1.2 & 1 \\
\hline ВЛ 110 кВ Береговая -2 - Береговая-1 & 150 & 14.6 & 12.9 \\
\hline \multicolumn{4}{|c|}{ Вывод в ремонт ВЛ 110 кВ АТЭЦ- Смоляниново/т } \\
\hline ВЛ 110 кВ Смоляниново/т - Садовая & 596 & 58.2 & 51.5 \\
\hline ВЛ 110 кВ Садовая - Береговая -1 & 596 & 58.2 & 51.5 \\
\hline ВЛ 110 кВ Береговая -2 - Береговая-1 & 626 & 61.1 & 54.1 \\
\hline
\end{tabular}


Таблица 2.

Результаты расчета режимов варианта № 2

\begin{tabular}{|c|c|c|c|}
\hline Наименование ВЛ & $\begin{array}{c}\text { Tок, } \\
\text { A }\end{array}$ & $\begin{array}{c}\text { Токовая загрузка } \\
\text { ДДТН, \% }\end{array}$ & $\begin{array}{c}\text { Токовая загрузка } \\
\text { АДТН, \% }\end{array}$ \\
\hline \multicolumn{4}{|c|}{ Вывод в ремонт ВЛ 110 кВ Садовая - Смоляниново/т } \\
\hline ВЛ 110 кВ АТЭЦ - Смоляниново/т & 296 & 87.8 & 79 \\
\hline ВЛ 110 кВ Береговая -2 - Береговая-1 & 150 & 38.4 & 31 \\
\hline $\begin{array}{c}\text { ВЛ } 110 \text { кВ АТЭЦ -Западная - Кролевцы - Штыково } \\
\text { № } 1 \\
\end{array}$ & 394 & 87.6 & 71 \\
\hline $\begin{array}{c}\text { ВЛ } 110 \text { кВ АТЭЦ -Западная - Королевцы - } \\
\text { Штыково № } 2\end{array}$ & 395 & 87.9 & 71 \\
\hline Штыково - РП & 267 & 59.4 & 47 \\
\hline РП-Анисимовка/т & 127 & 32.5 & 23 \\
\hline \multicolumn{4}{|c|}{ Вывод в ремонт ВЛ 110 кВ Береговая - 1 - Садовая } \\
\hline ВЛ 110 кВ АТЭЦ - Смоляниново/т & 289 & 86.5 & 77 \\
\hline ВЛ 110 кВ Береговая -2 - Береговая-1 & 149 & 38.4 & 31 \\
\hline $\begin{array}{c}\text { ВЛ } 110 \text { кВ АТЭЦ -Западная - Кролевцы - Штыково } \\
\text { № } 1 \\
\end{array}$ & 395 & 87.8 & 71 \\
\hline $\begin{array}{c}\text { ВЛ } 110 \text { кВ АТЭЦ -Западная - Королевцы - } \\
\text { Штыково № } 2\end{array}$ & 396 & 88 & 71 \\
\hline Штыково - РП & 269 & 59.7 & 48 \\
\hline РП-Анисимовка/т & 126 & 32.4 & 23 \\
\hline \multicolumn{4}{|c|}{ Вывод в ремонт ВЛ 110 кВ АТЭЦ- Смоляниново/т } \\
\hline ВЛ 110 кВ Береговая -2 - Береговая-1 & 121 & 31 & 25 \\
\hline ВЛ 110 кВ Смоляниново/т - Садовая & 74 & 21.9 & 19 \\
\hline ВЛ 110 кВ Садовая - Береговая -1 & 74 & 21.9 & 19 \\
\hline $\begin{array}{c}\text { ВЛ } 110 \text { кВ АТЭЦ -Западная - Кролевцы - Штыково } \\
\text { № } 1 \\
\end{array}$ & 530 & 11.8 & 95 \\
\hline $\begin{array}{c}\text { ВЛ } 110 \text { кВ АТЭЦ -Западная - Королевцы - } \\
\text { Штыково № } 2\end{array}$ & 531 & 118.1 & 95 \\
\hline Штыково - РП & 540 & 120.1 & 97 \\
\hline РП-Анисимовка/т & 94 & 21 & 17 \\
\hline
\end{tabular}

Таблица 3.

Результаты расчета режимов варианта № 3

\begin{tabular}{|c|c|c|c|}
\hline Наименование ВЛ & Ток, & $\begin{array}{c}\text { Токовая загрузка, в \% от } \\
\text { ДДТН }\end{array}$ & $\begin{array}{c}\text { Токовая загрузка, в \% от } \\
\text { АДТН }\end{array}$ \\
\hline \multicolumn{4}{|c|}{ Вывод в ремонт ВЛ 110 кВ Садовая - Смоляниново/т } \\
\hline ВЛ 110 кВ АТЭЦ - Смоляниново/т & 271 & 81.3 & 73 \\
\hline ВЛ 110 кВ Береговая -2 - Береговая-1 & 156 & 40 & 32 \\
\hline $\begin{array}{c}\text { ВЛ } 110 \text { кВ АТЭЦ -Западная - Кролевцы - } \\
\text { Штыково № } 1 \\
\end{array}$ & 386 & 85.7 & 69 \\
\hline $\begin{array}{c}\text { ВЛ } 110 \text { кВ АТЭЦ -Западная - Кролевцы - } \\
\text { Штыково № } 2\end{array}$ & 387 & 86 & 69 \\
\hline Штыково - РП & 250 & 55.6 & 45 \\
\hline РП-Анисимовка/т & 83 & 25.3 & 15 \\
\hline \multicolumn{4}{|c|}{ Вывод в ремонт ВЛ 110 кВ Береговая - 1 - Садовая } \\
\hline ВЛ 110 кВ АТЭЦ - Смоляниново/т & 273 & 81.7 & 73 \\
\hline ВЛ 110 кВ Береговая -2 - Береговая-1 & 156 & 40 & 32 \\
\hline $\begin{array}{c}\text { ВЛ } 110 \text { кВ АТЭЦ -Западная - Кролевцы - } \\
\text { Штыково № } 1\end{array}$ & 386 & 85,9 & 69 \\
\hline $\begin{array}{c}\text { ВЛ } 110 \text { кВ АТЭЦ -Западная - Кролевцы - } \\
\text { Штыково № } 2 \\
\end{array}$ & 388 & 86.1 & 70 \\
\hline Штыково - РП & 252 & 56 & 45 \\
\hline РП-Анисимовка/т & 83 & 25.3 & 15 \\
\hline \multicolumn{4}{|c|}{ Вывод в ремонт ВЛ 110 кВ АТЭЦ- Смоляниново/т } \\
\hline ВЛ 110 кВ Береговая -2 - Береговая-1 & 122 & 31.5 & 25 \\
\hline ВЛ 110 кВ Смоляниново/т - Садовая & 61 & 18 & 16 \\
\hline ВЛ 110 кВ Садовая - Береговая -1 & 61 & 18 & 16 \\
\hline $\begin{array}{c}\text { ВЛ } 110 \text { кВ АТЭЦ -Западная - Кролевцы - } \\
\text { Штыково № } 1\end{array}$ & 516 & 114.6 & 93 \\
\hline
\end{tabular}




\begin{tabular}{|c|c|c|c|}
\hline $\begin{array}{c}\text { ВЛ } 110 \text { кВ АТЭЦ-Западная - Королевцы - } \\
\text { Штыково № 2 }\end{array}$ & 517 & 114.9 & 93 \\
\hline Штыково - РП & 513 & 113.9 & 92 \\
\hline РП - Анисимовка/ & 55 & 16.6 & 10 \\
\hline
\end{tabular}

По результатам расчётов все предложенные варианты позволяют исключить превышение АДТН в рассмотренных ремонтных режимах. Превышения ДДТН считаем допустимыми так как длительность перегрузки меньше 20 минут.
Результаты технико-экономического сравнения предложенных вариантов приведены в таблице 4

Результаты экономических расчетов вариантов

\begin{tabular}{|c|c|c|c|c|}
\hline \multirow{2}{*}{} & \multicolumn{2}{|c|}{ Вариант №1* } & \multirow{2}{*}{ Вариант №2 } & \multirow{2}{*}{ Вариант №3 } \\
\cline { 2 - 3 } & Без замены опор & С заменой опор & 286.05 & 386.59 \\
\hline К,млн.руб. & 306.512 & 533.33 & 30.87 & 40.53 \\
\hline И, млн. руб. & 52.25 & 65.41 & 54.46 & 72.42 \\
\hline 3, млн. руб. & 77.54 & 109.41 & \\
\hline
\end{tabular}

Примечание: *Вариант технические не реализуем без ограничения нагрузки ПС Смоляниново/т на период замены провода.

Таким образом, наименее капиталоёмким и имеющим минимальные приведённые затраты мероприятием, позволяющим решить обозначенную проблему, является усиление сети 110 кВ путём строительства РП 110 кВ по схеме четырёхугольник с четырьмя заходами ВЛ 110 кВ.

\section{Список литературы:}

1.Костин, Н.А., Саблин, О.И. Коэффициент мощности электроподвижного состава постоянного тока // Электротехника и электромеханика. 2005. № 1

2.Методические рекомендации по проектированию развития энергосистем, утвержденные приказом Минэнерго от 30.062003г.

3.Отчет о научно-исследовательской работе по разработке схемы и программы развития электроэнергетики Приморского края на 2020-2024 годы /С.А.Портянков - М.: АО «Научнотехнический центр Единой Энергетической Системы (Московское отделение)», 2019. - 244 с.

$$
\text { 4.Правила технологического }
$$
функционирования электроэнергетических систем, утвержденные постановлением правительства Российской федерации от 13.08.2018 г. №937

5.Растрвин. Ру [Электронный ресурс]: - Режим доступа: http://www.rastrwin.ru.

6. Файбисович, Д.Л. Справочник по проектированию электрических сетей : справочник / Д.Л. Файбисович, И.Г. Карапетян. - 4-е изд., перераб. и доп. - М.: ЭНАС, 2012. - 376 с.

7. Характеристики провода АCСC [Электронный ресурс]: - Режим доступа: https://avatok.ru/

УДК 533.6.011.5

\section{ОСОБЕННОСТИ ТЕЧЕНИЯ ПЛОСКОГО СВЕРХЗВУКОГО ПОТОКА}

Цыбизов Ю.И.

Д.т.н.., профессор кафедры теплотехники и тепловых двигателей. Самарский университет, г. Самара

\section{АННОТАЦИЯ}

DOI: 10.31618/ESU.2413-9335.2020.2.76.905

Цель - исследование особенностей течения потока со сверхзвуковой скоростью при использовании в качестве параметров тангенциальной и радиальной составляющих конвективного ускорения и связанных с ними элементами характеристической сетки. Использование вводимых параметров позволяет расширить представления о зоне влияния возмущений и характере действующих сил, обусловливающих изоэнтропический разгон (торможение) потока и взаимно однозначное соответствие физической плоскости течения и годографа скорости. Полученные результаты предлагается использовать при решении задач прикладного характера и анализе экспериментальных исследований.

\section{ABSTRACT}

The purpose of this work is to study the characteristics of the flow with supersonic speed when using the tangential and radial components of convective acceleration and associated elements of the characteristic grid as parameters. Using input parameters allows to expand understanding of the zone of influence of disturbances and the nature of the forces contributing to isentropic acceleration (deceleration) of flow and one-to-one mapping between the physical plane and the hodograph of the velocity. The obtained results are proposed to be used in solving applied problems and analyzing experimental studies.

Ключевые слова: сверхзвуковой поток, тангенциальная и радиальная составляющие ускорения, 